GEOLOGICAL SURVEY CIRCULAR 717-C

\title{
Seismic Engineering Program Report, July-September 1975
}

Prepared on behalf of the National Science Foundation 
Seismic Engineering

Program Report,

July-September 1975

GEOLOGICAL SURVEY CIRCULAR 7I7-C

Prepared on behalf of the

National Science Foundation 


\section{United States Department of the Interior}

THOMAS S. KLEPPE, Secretary

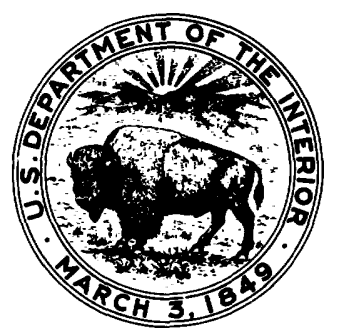

Geological Survey

V. E. McKelvey, Director 
This Seismic Engineering Program Report is an informal document intended to keep the ever-growing community of strong-motion data users apprised of the activities and data recovered by the U.S. Geological Survey in the Seismic Engineering Program of strongmotion instrumentation supported by the National Science Foundation (Grant CA-114) in cooperation with other Federal, State, and local agencies and organizations.

This report contains a list of the accelerograph records recovered during the second quarter of 1975, preliminary reports on earthquakes from which significant accelerograph records were recovered, and information on the avallability of digitized data. Future issues will contain similar information with all listed data as current as practicable under the constraints of the U.S.G.S. review and publication procedures. 
$-$ 


\section{SEISMIC ENGINEERING PROGRAM REPORT, JULY-SEPTEMBER 1975}

\section{ACCELEROGRAPH RECORDS APRIL - JUNE, 1975}

By R. P. Maley and B. L. Silverstein

During the second quarter of 1975, 29 accelerograph records were obtained from the strong-motion instrumentation network operated by the U.S. Geological Survey for the National Science Foundation in cooperation with other federal, state, and local agencies and organizations. This total represents the data recovered from 11 earthquakes ranging in magnitude from 3.6 to 6.0 that occurred in California, Alaska, Missouri, and Puerto Rico. Table 1 presents a chronological summary of the records including the maximum accelerations for those records in which peak accelerations equaled or exceeded $0.05 \mathrm{~g}$ on the ground or $0.10 \mathrm{~g}$ on a structure.

The first known strong-motion accelerograph record obtained from an earthquake in the central United States was recorded during a magnitude 3.8 shock that occurred in southeastern Missouri on June 13. Maximum accelerations of $0.07 \mathrm{~g}$ and $0.06 \mathrm{~g}$ were registered by the horizontal components. The calculated epicentral distance, based upon information from St. Louis University (S. Morrissey, oral commun, 1975), was $10 \mathrm{~km}$. The S-wave minus trigger interval, which approximates the S-P interval within about a tenth of a second, was 0.3 second, indicating that the source-to-receiver distance was relatively small.

Two minor records were recovered at San Juan, Puerto Rico, from a magnitude 4.9 earthquake that occurred an estimated 110 $\mathrm{km}$ away.
Several accelerograms obtained friom California Institute of Technology stations during the Impertal Valley earthquake swarm of June 19 and 20 are not included in table 1 because the original records are not processed or archived by the U.S. Geological Survey, although the more significant results from these records are presented in a preliminary report, below.

PRELIMINARY REPORT ON THE IMPERIAL VALLEY EARTHQUAKE SWARM OF JUNE 19 AND 20, 1975

By Ronald L. Porcella and Edwin C. Etheredge

A swarm of earthquakes occurred in the Imperial Valley near El Centro, California on June 9 and 20, 1975. The largest shock had a magnitude of 4.2 (PAS) and occ rrred at 22:48 local time (PDT) Thursday, June 19, 1975. The epicenter was approximately $10 \mathrm{~km}$ east of E1 Centro at $32.77^{\circ} \mathrm{N}$ and $115.44^{\circ} \mathrm{W}$. A second shock of 4.1 magnitude occurred the following afternoon at $15: 15$ (PDT) at $32.78^{\circ}$ $\mathrm{N}$ and $115.43^{\circ} \mathrm{W}$ (fig. 1). Both shocks rattled windows and operated burglar alarms in the area but caused no reported damage (Imperial Valley Press, June 21, 1975). Seven strong-motion accelerographs maintained by the U.S. Geological Survey and the California Institute of Technology (CIT) Earthquake Engineering Research Laborator: were triggered by the series of earthquakes. In all, 10 accelerograph records and 3 seismoscope records were recovered from stations located between 5 and $15 \mathrm{~km}$ of the tro epicenters.

A similar swarm of earthquakes berinning on January 23, 1975 produced records at four accelerograph stations in the El Centro-Imp- 
erial area. Since that time 13 new stations have been established in the Imperial Valley by the USGS, CIT, and the California Division of Mines and Geology. Most of the new instruments are alined transverse to the Imperial fault zone at approximately $3-\mathrm{km}$ separations (fig. 1). These instruments complement an array along the fault insta11ed by CIT. Each instrument will be equipped with a vertical trigger and will have real time impressed on the records by WWVB radio receivers.

The largest accelerations were recorded during the magnitude 4.1 earthquake: $0.13 \mathrm{~g}$ at E1 Centro Array Sta 6 , and $0.15 \mathrm{~g}$ at Holtville (table 2). The largest earthquake, magnitude 4.2 , registéred somewhat smaller accelerations at the two sites: $0.10 \mathrm{~g}$ at E1 Centro Array Sta 6 , and $0.07 \mathrm{~g}$ at Holtville. Note that instruments located at shorter epicentral distances such as E1 Centro Array: Sta 7 and Sta 8 (fig. 1) were not triggexed by either event. This indicates that vertical acceleration did not exceed $0.01 \mathrm{~g}$ at these sites. A third shock, magnitude 3.6 on June 20, registered maximum accelerations of $0.03 \mathrm{~g}$ at both Holtville and E1 Centro Array Sta 6 .

The initial shear-wave motion on the horizontal components shown in figure 2 typically displays the relatively long period (2-3hz), high-amplitude characteristics associated with the shallow-focus, low-magnitude earthquakes in this region.

Because a number of the instruments operating during this earthquake series were equipped with vertical triggers, it is possible to identify $S$-wave minus trigger intervals, which ranged from 0.65 - 3.40 seconds. No such intervals were observed on the January 23 records when only horizontal triggers were being used.

During this investigation, six zones along the Imperial fault trace were inspected for evidence of recent ground displacement. The features checked were roadway surfaces and concrete-1ined irrigation ditches. of the six zones, five showed some previous horizontal displacement due to sudden faulting and/or creep. These same five locations had been previously noted by Brune and Allen (1967) as being areas where lateral offset was directly related to sudden faulting during the March 4, 1966 Imperial earthquake, which occurred $5 \mathrm{~km}$ west of the Tune 1975 epicenters. At two locations, $2 \mathrm{~km}$ north and $6 \mathrm{~km}$ south of El Centro Array: Sta 7 (fig. 1), en echelon cracking in roadway surfaces indicated small right-lateral displacements; however, none of the zones showed any evidence of renewed ground displacement that could be attributed specifically to the June 1975 earthquake activity. Numerous detailed photographs were taken of these localities for possible use in future offset determinations.

\section{Reference}

Brune, J. N. and Allen, C. R., 1967, A lowstress-drop, low-magnitude earthcuake with surface faulting; the Imperial, California earthquake of March 4, 1966: Seirmol. Soc. America Bull., v. 57, p. 510-514.

PRELIMINARY SUMMARY OF STRONG-MOTION DATA FROM THE OROVILLE EATT PUAKE OF 1 AUGUST 1975

By Richard P. Maley, B. J. Morrill, Russel1 Forshee, William Wells ${ }^{1}$, Harry LaGesse ${ }^{1}$, and Ross Stevens ${ }^{2}$

A strong earthquake occurred in northcentral California at 1320 Pacific Daylight Time (2020 GMT) on August 1, 1975. The University of California, Berkeley seismograph station reported the following information about the event: magnitude 5.7 ; location $39.44^{\circ} \mathrm{N}$ and $121.53^{\circ} \mathrm{W}$, approximately $8 \mathrm{~km}$ south of Oroville.

The earthquake was recorded br: five strong-motion accelerographs located less

1

California Division of Mines and Geology ${ }^{2}$ California Department of Water Resources 
than $35 \mathrm{~km}$ from the epicenter including two instruments installed at and near Oroville Dam approximately $12 \mathrm{~km}$ northeast of the epicenter (fig. 3). The Oroville Dam accelerographs, operated in a cooperative program between the California Department of Water Resources and USGS, are located on the dam crest and at a seismograph vault approximately $2 \mathrm{~km}$ northwest of the dam. A third instrument in the core block of the dam was inoperative at the time of the earthquake. The records from the seismograph vault and crest stations (fig. 4 and 5) show about 2-3 seconds of significant motion with maximum acceleration spikes of $0.13 \mathrm{~g}$ at both sites. Other than these few peaks the nominal acceleration values were somewhat less than $0.10 \mathrm{~g}$. The crest instrument had a delayed start and consequently a few seconds of data were lost during the early part of the earthquake. Note, that the top trace in figure 5 was recorded transverse to the axis of the dam, whereas the bottom trace was parallel to the axis. Table 3 summarizes the maximum acceleration values scaled from the more significant records. The two Oroville Dam records have been digitized for further processing and analysis.

Three other records were obtained from California Division of Mines and Geology instruments located north and south of the epicenter at distances between 28 and $34 \mathrm{~km}$ (fig. 3 and table 3). At two alluvial sites, Chico to the north and Marysville to the south, peak accelerations of $0.08 \mathrm{~g}$ and $0.07 \mathrm{~g}$, respectively, were recorded, whereas at a rock site, Paradise, the maximum acceleration was $0.04 \mathrm{~g}$. The instrument at Sutter Buttes, which was installed in a building erected on volcanic rock, was operational but was not triggered by the earthquake. Because the vertical trigger at this site is calibrated to start the instrument at $.0 .01 \mathrm{~g}$, it is assumed that at least the vertical accelerations were somewhat less than this value.

Several other smaller records were obtained from outlying stations as far away as Sacramento, Calif. and Reno, Nev. A minor foreshock record was recorded at Oroville
Dam crest, and a number of aftershccks were recorded at the dam and at Chico ard Marysville.

Seismoscope records were obtained from five stations operated in the Oroville area in cooperation with the California Department of Water Resources (fig. 6). With the exception of the Division of Highweys (DOH), records from each of the stations wrere recovered shortly after the main earthquake. Although normally there is no separation of earthquakes recorded on a seismoscrne plate, the magnitude of shocks before and after the main earthquake suggests that the records represent principally the motion of a single earthquake. Copies of the records are shown in figure 7.

The record from DOH was not picled up until August 4, and consequently it contains motion from all prior events. Because there was an offset in the zero position of the stylus, either during the later part of the main earthquake or some time shortly thereafter, there is a definite separation in the records. The offset indicates an apparent tilting of $5^{\circ}$ down to the southeast. Examination of the instrument showed that it was in good condition and that the stylus arm knife edges were still properly seated in the pivots. The reason for the zero position offset is not yet known. An apparent original error in reported orientation of the DOH record has been corrected in figure 7 and table 4 by a $50^{\circ}$ clockwise rotation. This error was discovered by a comparison of the zero position on aftershock records.

The DOH record exhibited a prom:nent pulsing or excitement of the natural frequency of the pendulum suspension which, in effect, places a time scale on the record. This will permit recovery of the acceleration time-history in later analysis. Otl ar seismoscope records have this characteristic, and analyses of them will be performed.

Although the seismoscope is intended to record only motion in the horizontal plane, a crude measure of the degree of relative vertical motion between the various sites 
can be made by comparing the number of times the stylus lifted off the record. A count of these skips suggests that the seismoscope at $\mathrm{DOH}$ received considerable vertical motion.

Table 4 lists the seismoscope results. The displacement values ranged from 0.9-4.2 $\mathrm{cm}$ and showed an apparent correlation with soil conditions, that is, those instruments on unconsolidated sediments recorded higher displacements than those on volcanic rock.

\section{THE PLEASANT VALLEY PUMPING PLANT RECORDS FROM THE THREE ROCKS EARTHQUAKE OF AUGUST 3, 1975}

\section{By R. B. Matthiesen}

A magnitude 4.8 earthquake occurred on August 3, 1975 at $36^{\circ} 27.5^{\circ} \mathrm{N}$ and $120^{\circ} 20.7^{\prime}$ W near Three Rocks, Calif. (data from the University of California, Berkeley seismograph station). Four strong-motion accelerograph records were obtained at the Pleasant Valley Pumping Plant of the Central Valley Water Project. Copies of the records are shown in figure 8.

Although these records are of small amplitude, the obvious differences in the character of the record from the switchyard compared to those from the base and ground level of the plant and the clear indication of modal response in the roof record suggest that these records may of significant value in a study of soil-structure interaction. The structure consists of a massive concrete base containing the intake tubes and pump units below grade, and a moment-resistant steel frame superstructure with reinforced brick up to the level of the overhead crane rails. The relative simplicity of the structure and its response suggests that further analyses and interpretation of these records will be relatively straightforward. The records are being digitized, and additional details on the structure and the site conditions are being obtained.

\section{AVAILABILITY OF DIGITIZE? DATA}

The February 9, 1971 San Fernando earthquake strong-motion records and most of the significant records prior to that earthquake have been digitized by the California Institute of Technology (CIT). The digitized data are presently available throigh CIT and the Environmental Data Service (ETS) of the National Oceanic and Atmospheric Administration (NOAA) in the following form:

California Institute of Technologr:

* Volume I form of data (uncorrected) is available on four magnetic tapss at a total cost of $\$ 400$.

* Volume II form of data (corrected) is available for 329 records on three magnetic tapes at a total.cost of $\$ 300$.

* Data are available on seven-track, 800 BPI formatted tape in BCD; a few other formats are also available.

* Inquiries should be addressed to: Earthquake Engineering Research Lab. California Institute of Technology Mail Code 104-44

Pasadena, CA 91125

(213) 795-6841, ext. 1232

Environmental Data Service:

* Volume I form of data (uncorrented) is available in punched card form (about 2000 cards each) for $\$ 20$ per event and on magnetic tape (seven- or nine-track) for $\$ 60$ per tape. The complete file of approximately 400 records is available on six magnetic tapes for $\$ 360$.

* Inquiries should be addressed to: National Geophysical and SolarTerestrial Data Center EDS/NOAA, Code 62

Boulder, CO 80302

(303) 499-1000, ext. 6472

Significant strong-motion records obtained since the San Fernando earthquake are being processed by the USGS. The availability of such data will be announcet in subsequent Program Reports. 
Table 1 - Summary of accelerogroph records: April-June 1975

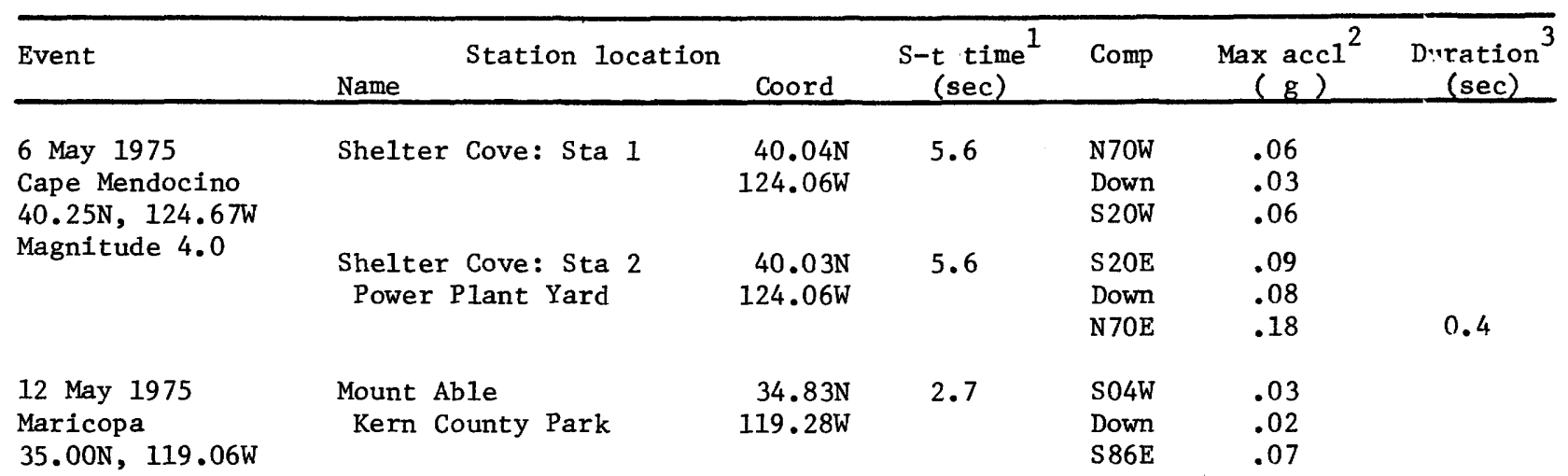

Small-amplitude records were also obtained at Mettler Ranch, E1khorn Scarp, Rudnick Ranch, and Buena Vista Pumping Plant.

18 May 1975

So cent Alaska

$63.2 \mathrm{~N}, 151.3 \mathrm{~W}$

Magnitude 6.0

31 May 1975

Mojave Desert

$34.51 \mathrm{~N}, 116.46 \mathrm{~W}$

Magnitude 5.2

7 June 1975

Humboldt County

$40.54 \mathrm{~N}, 124.29 \mathrm{~W}$

Magnitude 5.5
A small-amplitude record was obtained at Talkeetna. ${ }^{4}$

A small-amp1itude record was obtained at Amboy.

\begin{tabular}{|c|c|c|c|c|}
\hline $\begin{array}{l}\text { Ferndale } \\
\text { old City Hall }\end{array}$ & $\begin{array}{r}40.58 \mathrm{~N} \\
124.26 \mathrm{~W}\end{array}$ & $\begin{array}{l}\text { Up } \\
\text { S44W } \\
\text { N46W }\end{array}$ & $\begin{array}{l}.19 \\
.05 \\
.24\end{array}$ & \\
\hline $\begin{array}{l}\text { Cape Mendocino } \\
\text { Petrolia }\end{array}$ & $\begin{array}{r}40.35 \mathrm{~N} \\
124.35 \mathrm{~W}\end{array}$ & $\begin{array}{l}\text { S60E } \\
\text { Down } \\
\text { N30E }\end{array}$ & $\begin{array}{l}.22 \\
.03 \\
.14\end{array}$ & $\begin{array}{l}1.1 \\
1.8\end{array}$ \\
\hline $\begin{array}{l}\text { Petrolia } \\
\text { General Store }\end{array}$ & $\begin{array}{r}40.32 \mathrm{~N} \\
124.29 \mathrm{~W}\end{array}$ & $\begin{array}{l}\text { N75E } \\
\text { Down } \\
\text { N15W }\end{array}$ & $\begin{array}{l}.19 \\
.03 \\
.13\end{array}$ & $\begin{array}{l}1.7 \\
1.9\end{array}$ \\
\hline $\begin{array}{l}\text { Shelter Cove: Sta } 2 \\
\text { Power Plant Yard }\end{array}$ & $\begin{array}{r}40.03 \mathrm{~N} \\
124.06 \mathrm{~W}\end{array}$ & $\begin{array}{l}\text { S20E } \\
\text { Down } \\
\text { N70E }\end{array}$ & $\begin{array}{c}.10 \\
-07\end{array}$ & 1 peak \\
\hline
\end{tabular}

see footnotes at the end of table. 
Table 1 - Sumary of accelerograph records: Aprit-June 1975 - Continued

\begin{tabular}{|c|c|c|c|c|c|c|}
\hline Event & Station location & Coord & $\begin{array}{c}\mathrm{S}-\mathrm{t} \text { time } \\
(\mathrm{sec})\end{array}$ & Comp & $\begin{array}{c}\text { Max acc] }{ }^{2} \\
\quad(g) \\
\end{array}$ & $\begin{array}{c}\text { Duration } \\
(\mathrm{sec})\end{array}$ \\
\hline $\begin{array}{l}10 \text { June } 1975 \\
\text { So cent Alaska } \\
62.1 \mathrm{~N}, 149.9 \mathrm{~W} \\
\text { Magnitude } 4.4\end{array}$ & \multicolumn{6}{|c|}{ A small-amplitude record was obtained at Summit. ${ }^{4}$} \\
\hline $\begin{array}{l}13 \text { June } 1975 \\
\text { SE Missouri } \\
36.54 \mathrm{~N}, 89.68 \mathrm{~W} \\
\text { Magnitude } 4.3\end{array}$ & $\begin{array}{l}\text { New Madrid } \\
\text { Noranda Aluminum } \\
\text { Plant }\end{array}$ & $\begin{array}{l}36.51 \mathrm{~N} \\
89.57 \mathrm{~W}\end{array}$ & 0.3 & $\begin{array}{l}\text { S19W } \\
\text { Down } \\
\text { N71W }\end{array}$ & $\begin{array}{l}.06 \\
.04 \\
.07\end{array}$ & \\
\hline $\begin{array}{l}17 \text { June } 1975 \\
\text { Puerto Rico } \\
19.10 \mathrm{~N}, 66.85 \mathrm{~N} \\
\text { Magnitude } 4.9\end{array}$ & \multicolumn{6}{|c|}{$\begin{array}{l}\text { Small-amplitude records obtained from San Juan, VA Hospital and } \\
\text { the Capacete-Martin Building. }\end{array}$} \\
\hline \multirow{3}{*}{$\begin{array}{l}19 \text { June } 1975 \\
\text { Imperial Valley } \\
32.77 \mathrm{~N}, 115.44 \mathrm{~W} \\
\text { Magnitude } 4.2\end{array}$} & $\begin{array}{l}\text { E1 Centro Array: Sta } 6 \\
551 \text { Huston }\end{array}$ & $\begin{array}{r}32.84 \mathrm{~N} \\
115.49 \mathrm{~W}\end{array}$ & 2.7 & $\begin{array}{l}\text { S52W } \\
\text { Down } \\
\text { S38E }\end{array}$ & $\begin{array}{l}.06 \\
.02 \\
.10\end{array}$ & \multirow[t]{2}{*}{1 peak } \\
\hline & $\begin{array}{l}\text { E1 Centro } \\
\text { Meadows Union School } \\
2059 \text { Bowker }\end{array}$ & $\begin{array}{r}32.80 \mathrm{~N} \\
115.47 \mathrm{~W}\end{array}$ & 0.7 & $\begin{array}{l}\text { S52W } \\
\text { Down } \\
\text { S38E }\end{array}$ & $\begin{array}{l}.06 \\
.02 \\
.04\end{array}$ & \\
\hline & \multicolumn{6}{|c|}{$\begin{array}{l}\text { Small-amplitude records were also obtained from E1 Centro: Imperial } \\
\text { Valley Irrigation District Substation, and E1 Centro Array: Sta } 11 .\end{array}$} \\
\hline $\begin{array}{l}20 \text { June } 1975 \\
\text { Imperial Valley } \\
1415 \text { PST }\end{array}$ & $\begin{array}{l}\text { E1 Centro Array: Sta } 6 \\
551 \text { Huston }\end{array}$ & $\begin{array}{r}32.84 \mathrm{~N} \\
115.49 \mathrm{~W}\end{array}$ & 3.1 & $\begin{array}{l}\text { S52W } \\
\text { Down } \\
\text { S 38E }\end{array}$ & $\begin{array}{l}.10 \\
.05 \\
.13\end{array}$ & .1 \\
\hline $\begin{array}{l}32.78 \mathrm{~N}, 115.43 \mathrm{~W} \\
\text { Magnitude } 4.1\end{array}$ & \multicolumn{6}{|c|}{$\begin{array}{l}\text { A small-amplitude record was also obtained at E1 Centro, Imperial } \\
\text { Valley Irrigation District Substation. }\end{array}$} \\
\hline $\begin{array}{l}20 \text { June } 1975 \\
1855 \text { PST } \\
\text { Imperial Valley } \\
32.77 \mathrm{~N}, 115.43 \mathrm{~W} \\
\text { Magnitude } 3.6\end{array}$ & \multicolumn{6}{|c|}{ A smal1-amplitude record was obtained at E1 Centro Array: Sta 6.} \\
\hline
\end{tabular}

$1_{S-\text { wave minus trigger time. }}$

2Unless otherwise noted, maximum acceleration recorded at ground or basement level.

Data from the records are summarized only if the maximum acceleration is greater than $0.05 \mathrm{~g}$ at ground stations or greater than $0.10 \mathrm{~g}$ at upper floors of buildings.

3 Duration for which peaks of acceleration exceed $0.10 \mathrm{~g}$.

${ }^{4}$ These records could not be positively identified with the listed earthquakes. 
Table 2 - Sumary of accelerograph records from the Imperial Valley earthquake swarm of June 19 and 20, 1975

\begin{tabular}{llcc}
\hline Station & Maximum & S-wave minus & Epicentral \\
acceleration & trigger time & distance \\
$(\mathrm{g})$ & $(\mathrm{km})$ & \\
\hline
\end{tabular}

\begin{tabular}{|c|c|c|c|c|}
\hline \multirow[b]{2}{*}{$\begin{array}{l}\text { Meadows Union } \\
\text { School }\end{array}$} & \multicolumn{4}{|c|}{ Earthquake of June 19 , magnitude 4.2} \\
\hline & & .04 & .65 & 5.0 \\
\hline Holtville & & .07 & 2.30 & 6.4 \\
\hline E1 Centro: Sta 3 & Not & triggered & - & - \\
\hline E1 Centro: Sta 6 & & .10 & 2.70 & 9.6 \\
\hline E1 Centro: Sta 9 & & .03 & -1 & 11.4 \\
\hline E1 Centro: Sta 11 & & .03 & 2.95 & 15.1 \\
\hline \multirow[t]{2}{*}{ Calexico } & & .03 & 1.40 & 12.4 \\
\hline & \multicolumn{4}{|c|}{ Earthquake of June 20 , magnitude 4.1} \\
\hline $\begin{array}{l}\text { Meadows Union } \\
\text { School }\end{array}$ & Not & triggered & - & - \\
\hline Holtville & & .15 & 2.20 & 5.7 \\
\hline E1 Centro: Sta 3 & & .03 & 3.40 & 13.1 \\
\hline E1 Centro: Sta 6 & & .13 & 3.05 & 8.7 \\
\hline E1 Centro: Sta 9 & & .01 & -1 & 11.3 \\
\hline E1 Centro: Sta 11 & Not & triggered & - & - \\
\hline Calexico & Not & triggered & - & - \\
\hline
\end{tabular}

${ }^{1}$ Instrument equipped with a horizontal starter so that the S-wave minus trigger interval is not meaningful. 
Table 3 - Sumary of accelerograph data from stations within $50 \mathrm{~km}$ of the Oroville earthquake

\begin{tabular}{|c|c|c|c|c|c|c|}
\hline Station & $\begin{array}{l}\text { Instru- } \\
\text { ment }\end{array}$ & $\begin{array}{c}\text { Epicentral } \\
\text { distance } \\
(\mathrm{km})\end{array}$ & Soil & Component & $\begin{array}{l}\text { Maximum } \\
\text { acce1 } \\
\text { (g) }\end{array}$ & Remarks \\
\hline Chico & SMA-1 & 33 & Alluvium & $\begin{array}{l}\text { S 33W } \\
\text { Down } \\
\text { S57E }\end{array}$ & $\begin{array}{l}.08 \\
.03 \\
.06\end{array}$ & \\
\hline Marysville & SMA-1 & 32 & Alluvium & $\begin{array}{l}\text { S85W } \\
\text { Down } \\
\text { S05E }\end{array}$ & $\begin{array}{l}.07 \\
.04 \\
.06\end{array}$ & \\
\hline $\begin{array}{l}\text { Oroville Dam } \\
\text { crest }\end{array}$ & $\mathrm{AR}-240$ & 11 & $\begin{array}{l}\text { Earthfill } \\
\text { dam }\end{array}$ & $\begin{array}{l}\text { N46E } \\
\text { Down } \\
\text { N44W }\end{array}$ & $\begin{array}{l}.12 \\
.13 \\
.09\end{array}$ & $\begin{array}{l}\text { First few } \\
\text { seconds of } \\
\text { record lost }\end{array}$ \\
\hline $\begin{array}{l}\text { Oroville Dam } \\
\text { seismograph } \\
\text { station }\end{array}$ & $\begin{array}{l}\text { USC\&GS } \\
\text { Standard }\end{array}$ & 12 & $\begin{array}{l}\text { Meta- } \\
\text { volcanic } \\
\text { rock }\end{array}$ & $\begin{array}{l}\text { N53W } \\
\text { Up } \\
\text { N37E }\end{array}$ & $\begin{array}{l}.10 \\
.13 \\
.11\end{array}$ & \\
\hline Paradise & SMA-1 & 32 & Volcanic & $\begin{array}{l}\text { S07E } \\
\text { Down } \\
\text { N83E }\end{array}$ & $\begin{array}{l}.03 \\
.03 \\
.04\end{array}$ & \\
\hline $\begin{array}{l}\text { Sutter } \\
\text { Buttes }\end{array}$ & SMA-1 & 35 & $\begin{array}{l}\text { Rock } \\
\text { (andesite } \\
\text { porphyry) }\end{array}$ & & & $\begin{array}{l}\text { Was not } \\
\text { triggered }\end{array}$ \\
\hline
\end{tabular}


Table 4 - Summary of seismoscope results from the Oroville earthquake

\begin{tabular}{|c|c|c|c|c|c|}
\hline Station & $\begin{array}{l}\text { Direction to } \\
\text { epicenter } \\
\text { (degrees) }\end{array}$ & $\begin{array}{c}\text { Epicentra1 } \\
\text { dis tance } \\
(\mathrm{km})\end{array}$ & Soil & $\begin{array}{c}\mathrm{S}_{\mathrm{d}} \\
(\mathrm{cm})\end{array}$ & $\begin{array}{l}\mathrm{S}_{\mathrm{d}} \text { direction } \\
\text { (degrees) }\end{array}$ \\
\hline $\begin{array}{l}\text { Division of } \\
\text { Highways }\end{array}$ & 150 & 7.5 & Alluvium & 4.2 & $238^{1}$ \\
\hline $\begin{array}{l}\text { Division of } \\
\text { Forestry }\end{array}$ & 161 & 10.6 & $\begin{array}{l}\text { Compacted } \\
\text { clay, silt, } \\
\text { and sand }\end{array}$ & 2.7 & 047 \\
\hline Fire station & 163 & 8.2 & $\begin{array}{l}\text { Compacted } \\
\text { clay, silt, } \\
\text { and sand }\end{array}$ & 1.6 & 275 \\
\hline Hill residence & 181 & 9.7 & $\begin{array}{l}\text { Volcanic } \\
\text { and sedi- } \\
\text { mentary } \\
\text { rock }\end{array}$ & 1.0 & 270 \\
\hline $\begin{array}{l}\text { Seismograph } \\
\text { station }\end{array}$ & 190 & 12.5 & $\begin{array}{l}\text { Meta- } \\
\text { volcanic } \\
\text { rock }\end{array}$ & 0.9 & 106 \\
\hline
\end{tabular}

$1_{\text {Corrected } 50^{\circ} \text { clockwise. }}$ 
- Triggered accolerographs

$X$ Nontriggered accelerographs

$\oplus$ Earthquake epicenter

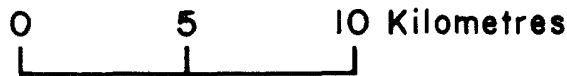

\section{$x$}

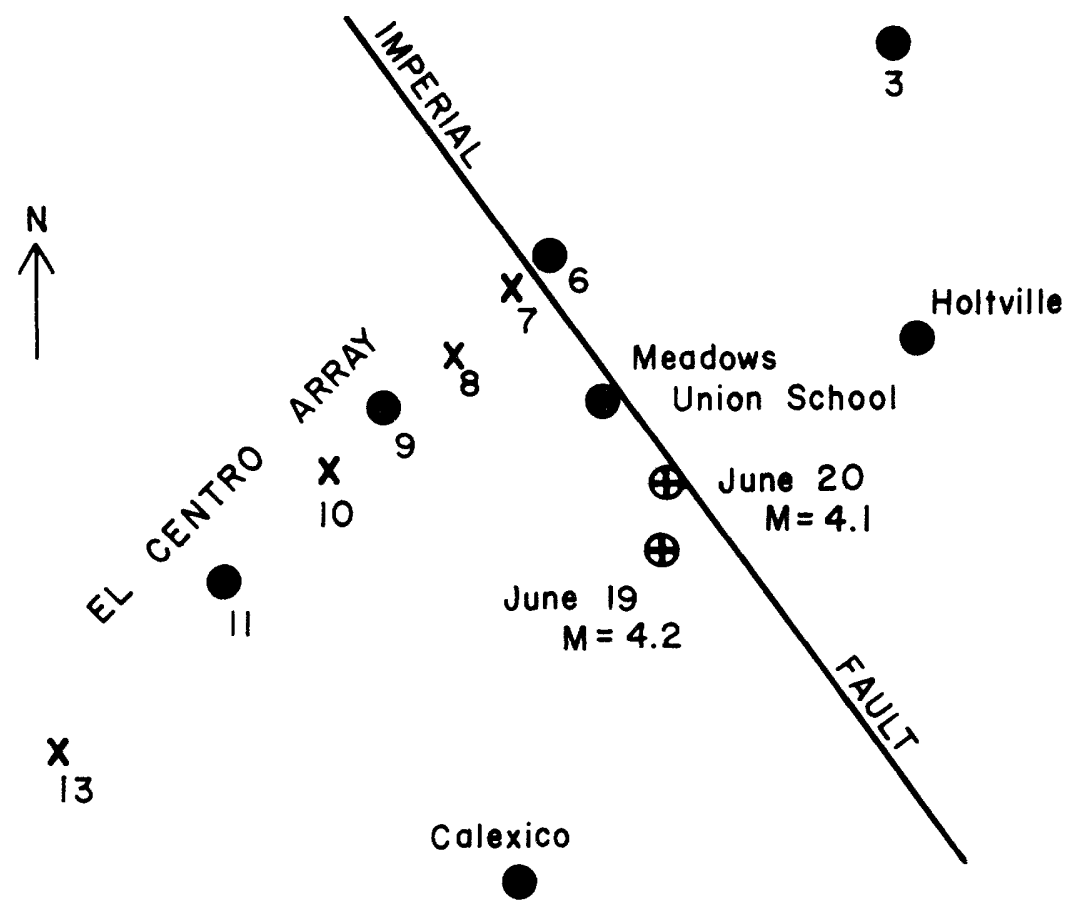

Figure 1. Accelerograph stations located in Imperial Valley during the earthquakes of June 19 and 20,1975 . 
YMunmom

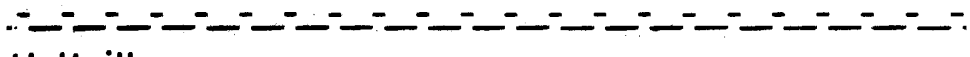
Holtville

\section{Earthquake of 20 June, $M=4.1$}

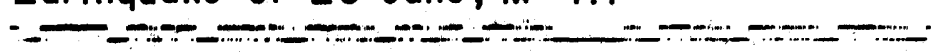

F

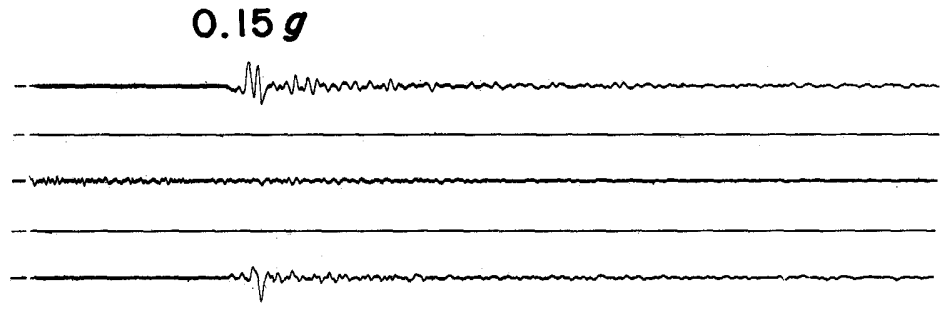

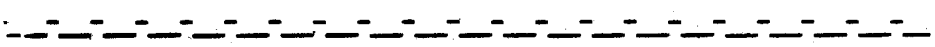
Holtville
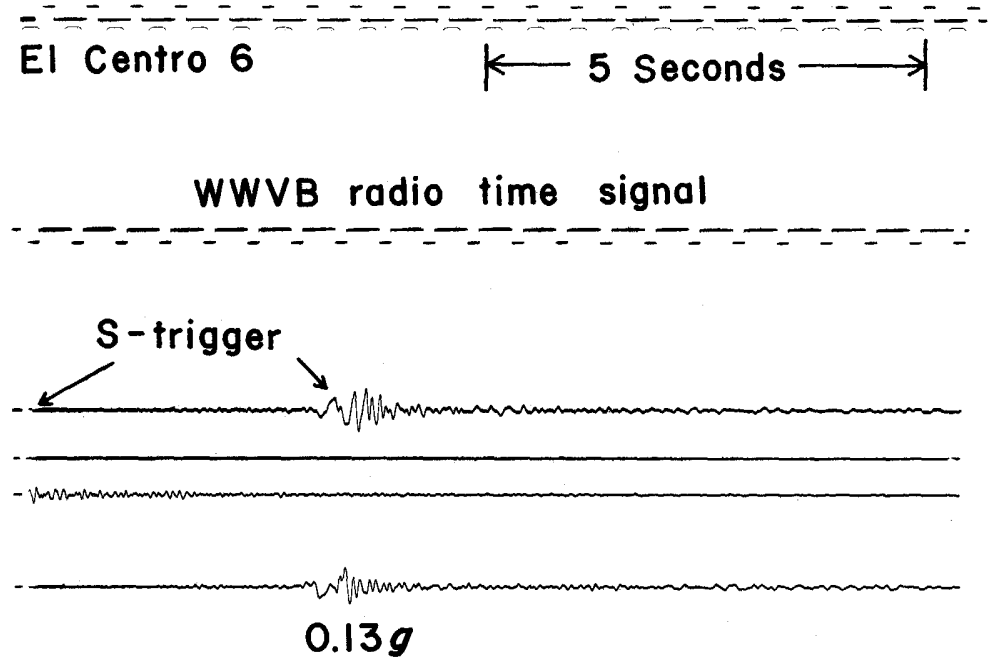

El Centro 6

Figure 2. Holtville and El Centro accelerograph records from the earthquakes of June 19 and $20,1975$. 


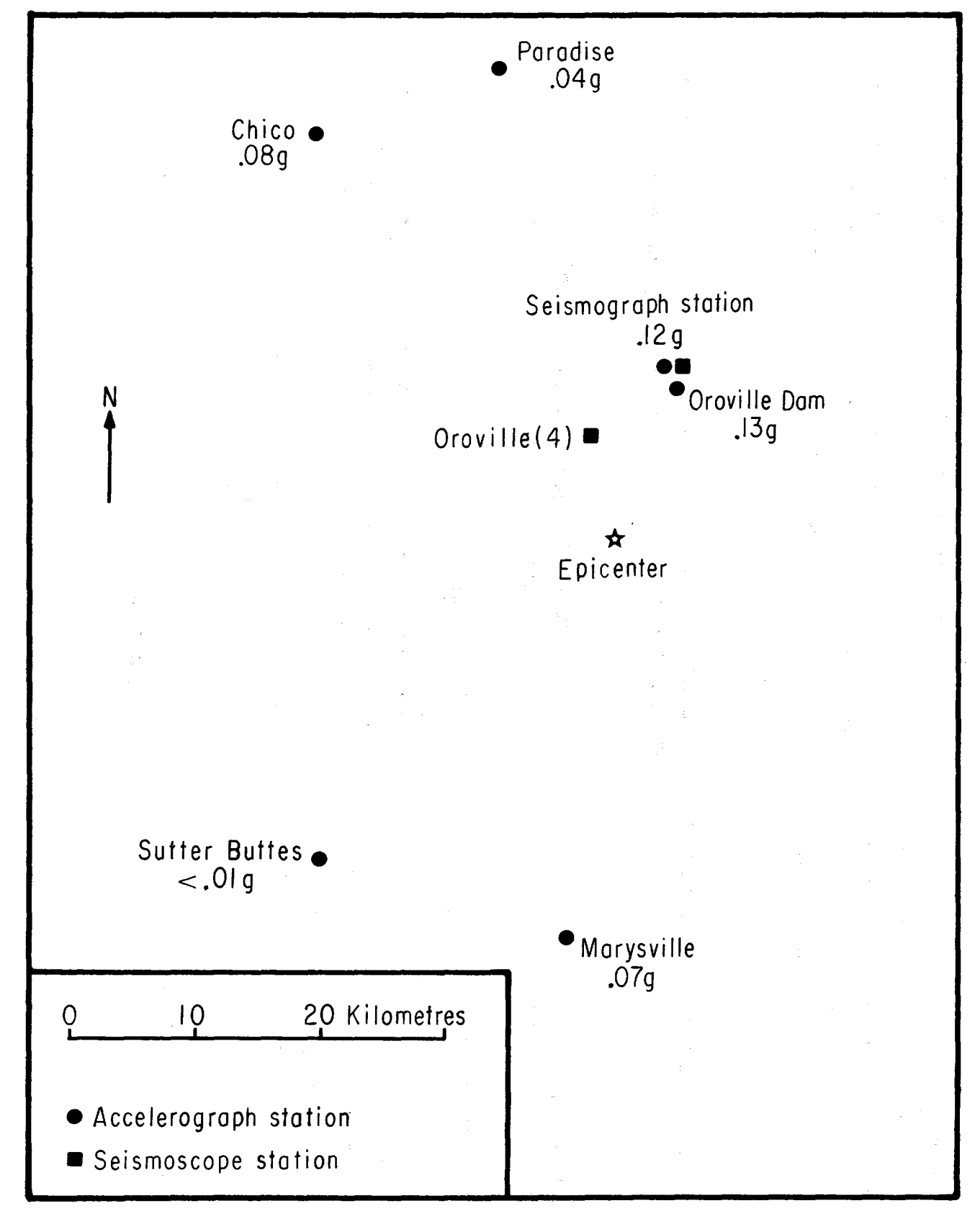

Figure 3. Location of strong-motion accelerographs near the Oroville earthquake; peak recorded accelerations are shown below the station names. No record was obtained at Sutter Buttes, consequently the maximum acceleration at this site is assumed to be less than the instrument's triggering threshold of $0.10 \mathrm{~g}$. 

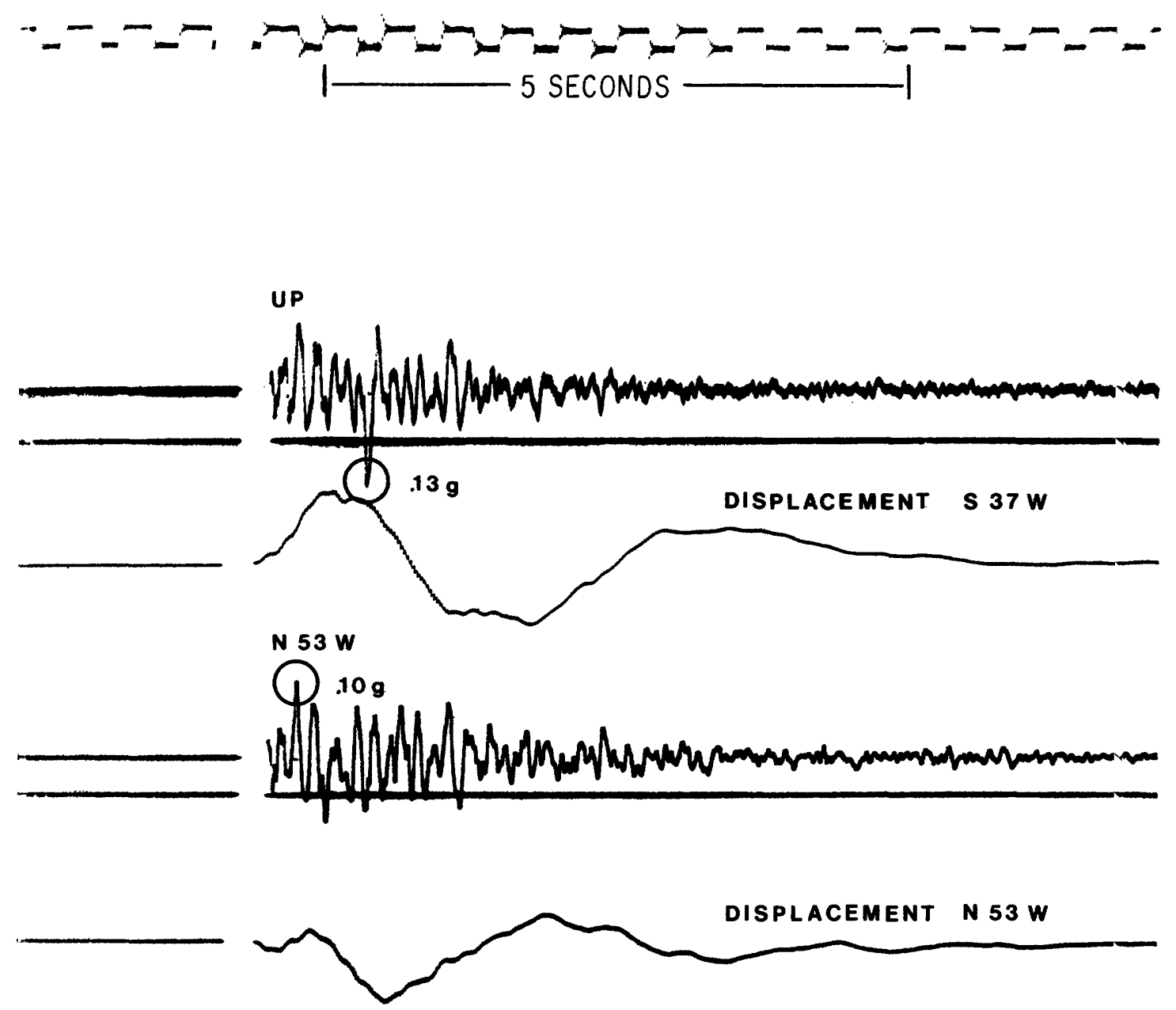

N $37 E$

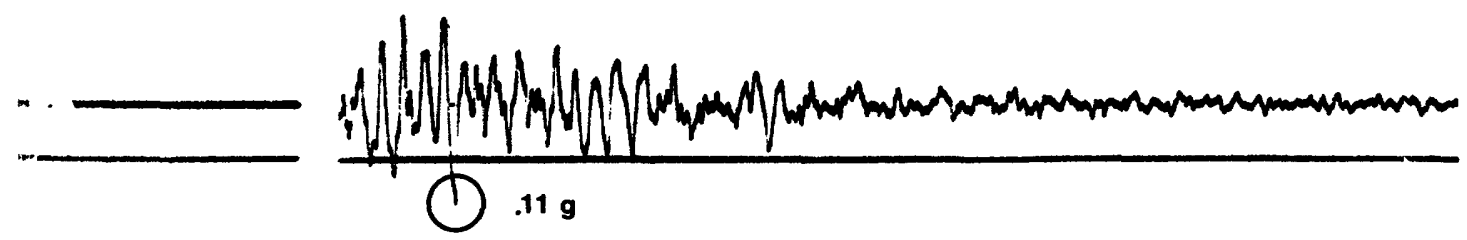

Figure 4. Tracing of the accelerograph record from the Oroville seismogranh station about $2 \mathrm{~km}$ northwest of the dam. 


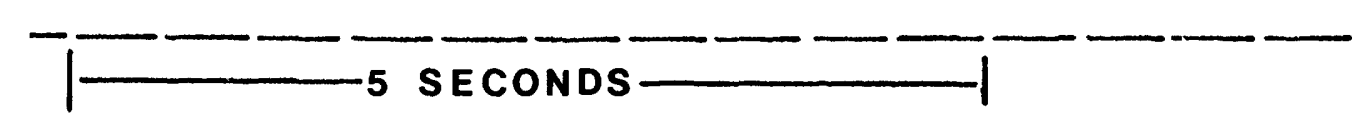

N 46 E

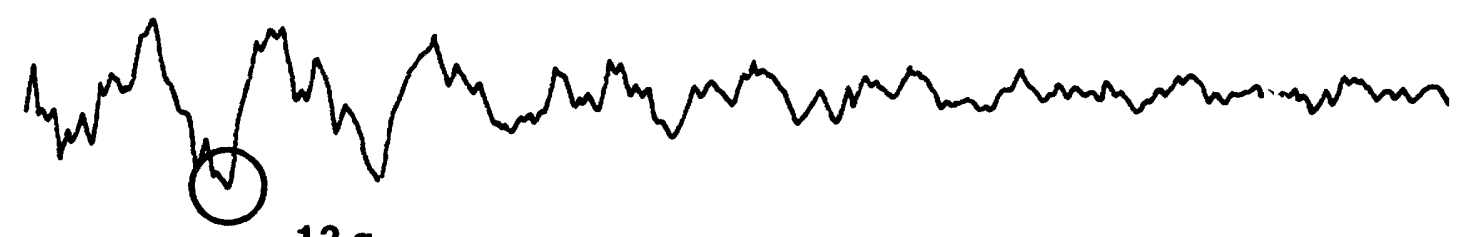
$.12 \mathrm{~g}$

\section{DOWN}

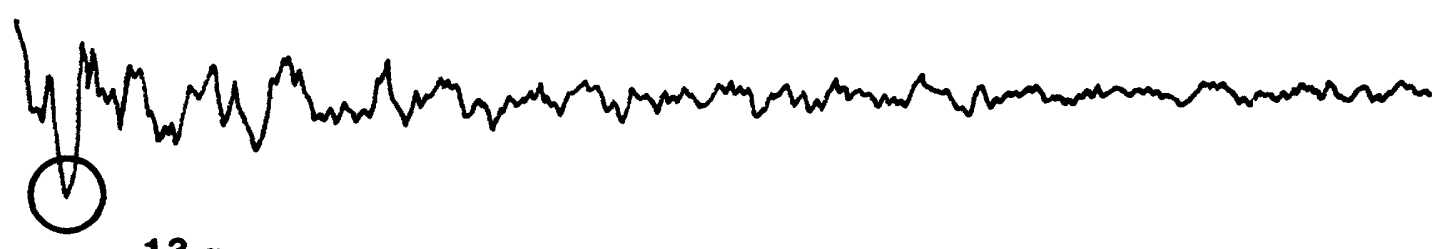
$.13 \mathrm{~g}$

N 44 W

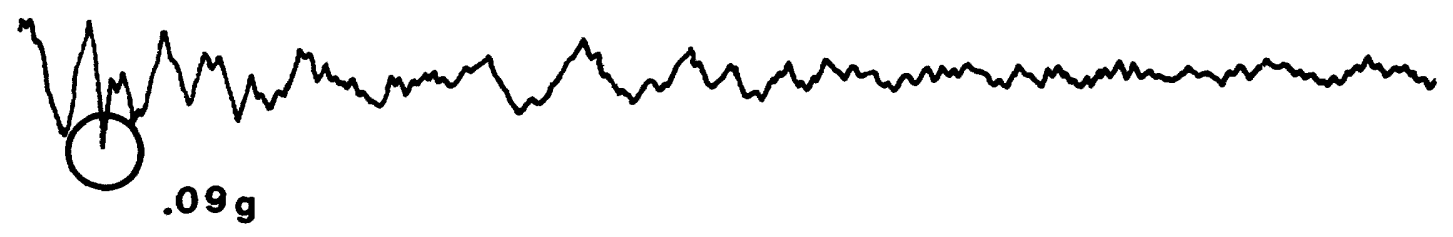

Figure 5. Tracing of the accelerograph record from the crest of Oroville Dam. 


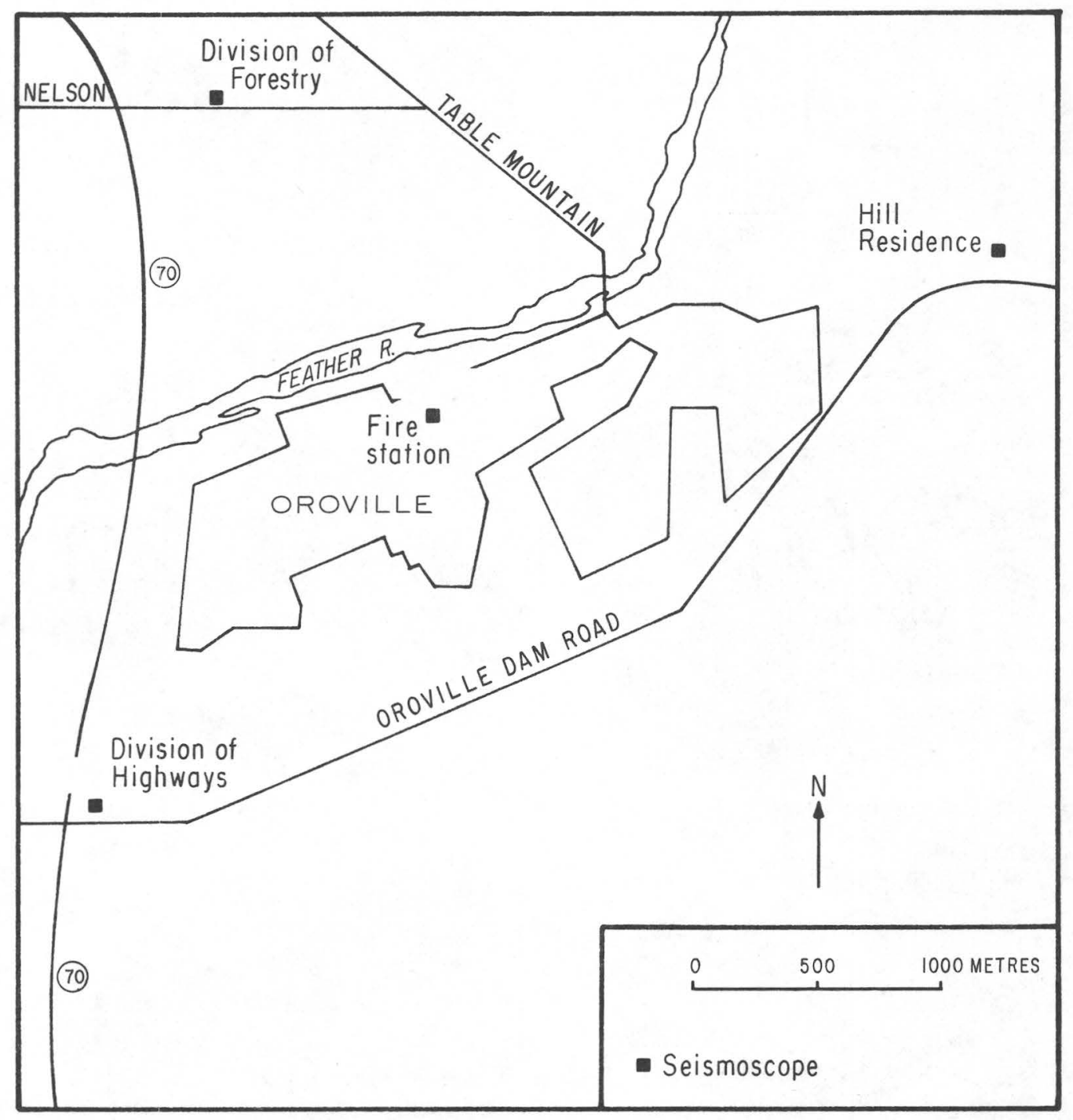

Figure 6. Sites of the four seismoscopes installed in the Oroville area. A fifth instrument is located near Oroville Dam, $7 \mathrm{~km}$ northeast of the city. 

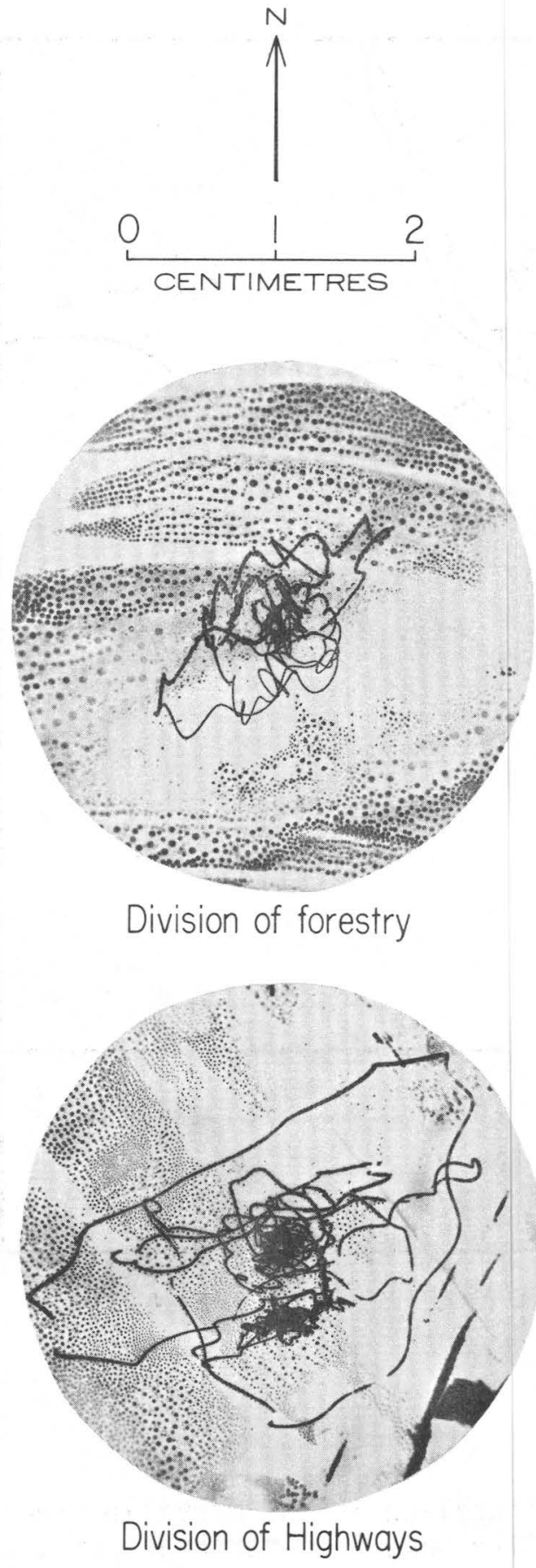

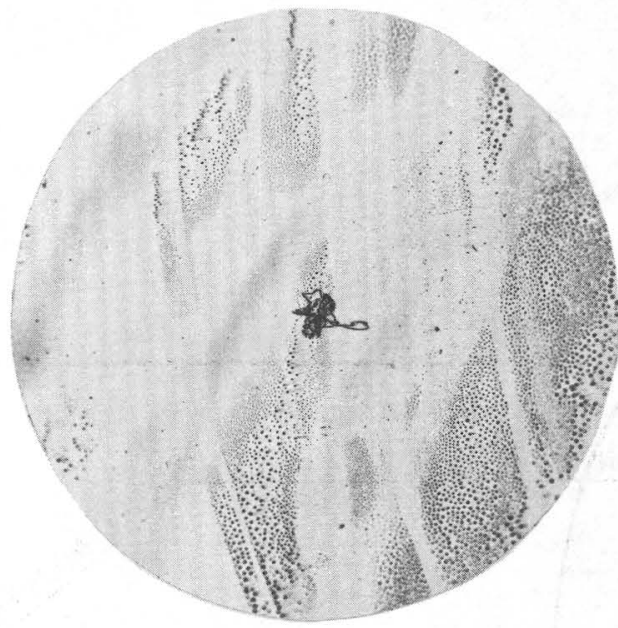

Seismograph station
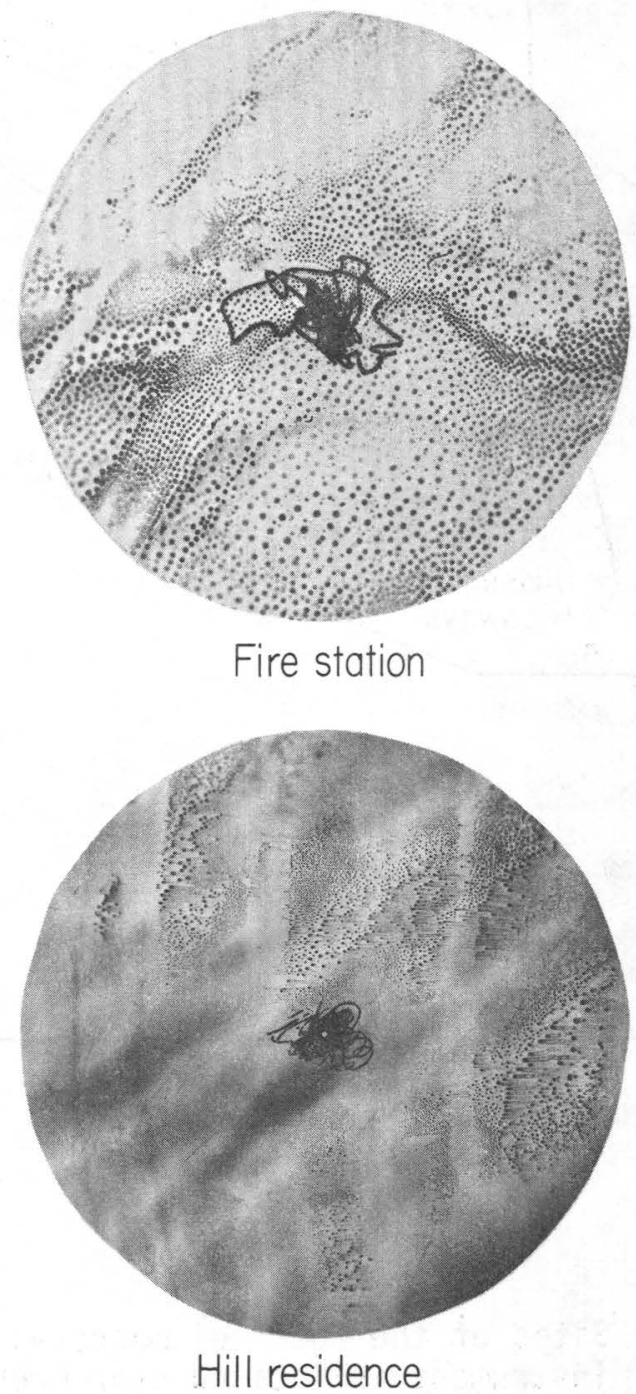

Figure 7. Copies of seismoscope records. Note the relatively large amplitudes exhibited by those records obtained farthest to the west. 
iN $45 \mathrm{E}$

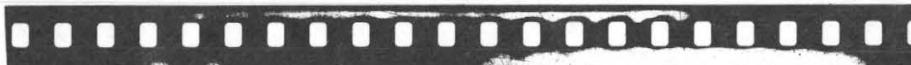

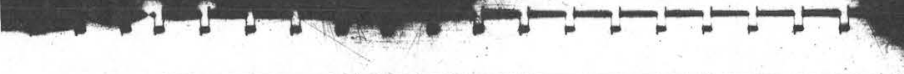

2
0
0
0
0
0
0
1
0

Down

N45W

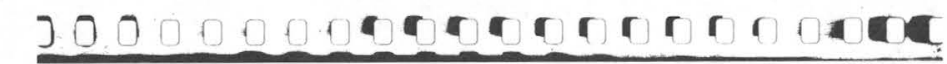

Roof

$k-5$ Seconds $\longrightarrow$

$\stackrel{\sqcup}{\sim}$

N44W

-

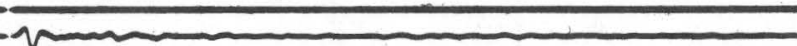

Down

S46W

Main level

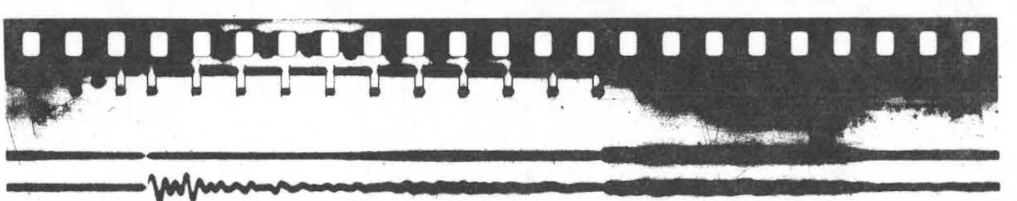

noming

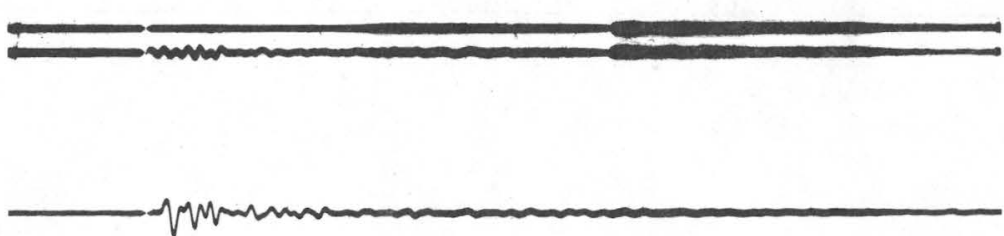

\section{Switchyard}
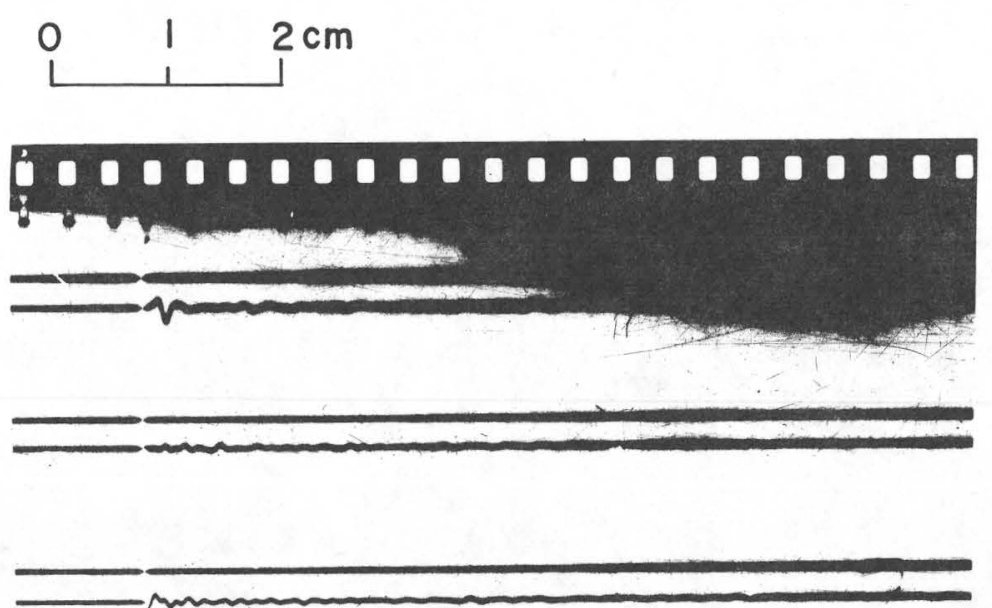

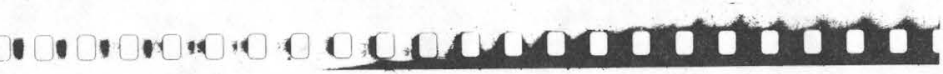
Basement

Figure 8. Accelerograph records from the Pleasant Valley Pumping Plant during the earthquake of August 3, 1975. 


